\title{
PENGARUH CURRENT RATIO, RETURN ON EQUITY DAN DEBT TO ASSET RATIO TERHADAP PRICE BOOK VALUE PERUSAHAAN ADVERTISING, PRINTING DAN MEDIA YANG TERDAFTAR DI BURSA EFEK INDONESIA PERIODE 2014-2017
}

\author{
Bayu Nur Batin \\ Bnur430@gmail.com \\ Universitas Ahmad Dahlan \\ Deny Ismanto \\ denoxis@yahoo.com \\ Universitas Ahmad Dahlan
}

\begin{abstract}
ABSTRAK
This research was conducted with the aim of partially testing the influence of Current Ratio, Return On Equity, and Debt to Asset Ratio on Price Book Value to Advertising, Printing and Media companies listed on the Indonesia Stock Exchange (IDX). Factors that influence price book value (PBV) include liquidity that is proxied by current ratio or current ratio (CR), profitability projected with return on equity (ROE), and Debt to asset ratio (DAR). The research period was carried out for 4 (four) years, namely 2014-2017. This type of research is Quantitative data, namely data in the form of numbers, or Quantitative data that are sent in a queue. The population in this study is a company engaged in the services of Advertising, Printing, and Media services listed on the IDX, namely 15 companies. The sample in this study was obtained by purposive sampling method. Based on existing criteria, 15 companies were obtained. Hypothesis testing is done by Multiple regression analysis, but before testing hypotheses first testing the classical assumptions. The results of hypothesis testing are carried out partially, namely the $t$ test shows that CR has no effect and is not significant on PBV. ROE has a partial and significant effect on PBV. DAR partially has no effect and is not significant for PBV.
\end{abstract}

Keywords: Current Ratio, Return On Equity, Debt to Asset Ratio, Price Book Value.

\section{PENDAHULUAN}

Dengan adanya pengaruh global menciptakan persaingan yang sangat kuat, dimana setiap perusahaan diharuskan untuk berusaha dan dapat menguasai pasar yang seluas-luasnya agar dapat mencapai tujuan yang diinginkan perusahaan. Dalam persaingan global menyebabkan peluang resiko kebangkrutan akan bertambah. Resiko kebangkrutan dapat dilihat dan diukur melalui laporan keuangan, dengan cara melakukan analisis terhadap laporan keuangan yang dibuat oleh perusahaan yang bersangkutan. Laba yang diperoleh perusahaan umumnya digunakan sebagai dasar untuk pengambilan keputusan investasi dan prediksi untuk perubahan laba yang akan datang. Perubahan laba akan berpengaruh terhadap keputusan investasi para investor yang akan menanamkan modalnya kedalam perusahaan. Laba mencerminkan kinerja perusahaan dan kondisi kesehatan keuangan perusahaan. Kesehatan suatu perusahaan akan mencerminkan kemampuan perusahaan dalam menjalankan usahanya, distribusi aktivanya, keefektifan penggunaan aktivanya, hasil usaha atau pendapatan 
yang telah dicapai, beban-beban tetap yang harus dibayar, serta potensi kebangkrutan yang akan dialami (Brahmana, 2007).

Kondisi persaingan di industri advertising, printing dan media saat in semakin ketat. Melihat persaingan pasarnya, media cetak sebenarnya sedikit kalah saing dengan media massa lainnya seperti media televisi maupun online, kecanggihan teknologi keduanya mampu mempengaruhi masyarakat sehingga menjadi beralih mengkonsumsi media massa di banding media cetak demi mendapatkan berita atau informasi yang cenderung cepat saji. Dalam hal ini perusahaan media cetak harus mencari inovasi dan terobosan baru agar dapat bertahan. Tantangan terbesar dari media cetak adalah bukan melawan media online, namun menyelaraskan diri dengan perkembangan media online yang saat ini lebih dipilih masyarakat dalam memperoleh informasi. Persaingan antar media televisi juga semakin ketat, karena perusahaan harus selalu mengembangkan inovasi dan terobosan baru demi memperoleh posisi terdepan di hati konsumen, dengan adanya karyawan yang berintelektual tinggi akan mendorong kinerja perusahaan menjadi lebih baik, hal ini dapat menarik perhatian investor sehingga nilai perusahaan juga akan bertambah. Jika kinerja perusahaan memburuk, nilai perusahaan juga akan turun.

Manajemen berperan dalam mengambil keputusan terhadap hasil laporan keuangan. Apabila kinerja keuangan perusahaan dalam keadaan menurun bahkan kesulitan keuangan maka manajer perlu mengambil keputusan dengan cepat untuk menghindari kebangkrutan. Untuk melihat keadaan perusahaan yang sedang memperihatinkan atau melihat tingkat resiko kebangkrutan. Salah satu cara untuk melihat kinerja keuangan perusahaan yaitu dengan menggunakan rasio keuangan.

Apabila PBV rasio harga per nilai buku terlalu mahal, maka saham akan tidak laku dijual atau tidak menarik investor untuk membelinya. Hal ini dapat dibuktikan dengan adanya perusahaanperusahaan yang go public di BEI melakukan stock split (pemecahan saham) di bursa efek. Harga saham harus dapat dibuat seoptimal mungkin artinya, harga saham tidak boleh terlalu tinggi (mahal) atau tidak boleh terlalu rendah (murah). Harga saham yang terlalu rendah berdampak buruk pada citra perusahaan dipandangan para investor. Harga saham yang optimal dapat dicapai melalui penarikan kesimpulan dari serangkaian pengalaman perusahaan dalam menjual saham di bursa efek. Artinya, bila pasar sangat tertarik dengan saham yang diperdagangkan, maka perusahaan dapat menaikkan harga sahamnya, demikian juga sebaliknya (Adyatma, 2015).

Tujuan dari penelitian ini adalah: 1) untuk menguji pengaruh Current Ratio (CR) terhadap Price Book Value (PBV) perusahaan sub sektor advertising, printing dan media yang terdaftar pada Bursa Efek Indonesia (BEI) periode tahun 2014-2017, 2) untuk menguji pengaruh Return On Equity (ROE) terhadap Price Book Value (PBV) perusahaan sub sektor advertising, printing dan media yang terdaftar pada Bursa Efek Indonesia (BEI) periode tahun 2014-2017 dan 3) untuk menguji pengaruh Debt to Asset Ratio (DAR) terhadap Price Book Value (PBV) perusahaan sub sektor advertising, printing dan media yang terdaftar pada Bursa Efek Indonesia (BEI) periode tahun 2014-2017. 


\section{REVIEW LITERATUR DAN HIPOTESIS}

\section{Landasan Teori}

1. Nilai Perusahaan

PBV adalah rasio atas harga pasar saham terhadap nilai bukunya yang juga akan memberi indikasi yang lain tentang bagaimana investor memandang perusahaan. Perusahaan dengan tingkat pengembalian ekuitas yang relatif tinggi biasanya menjual dengan perkalian nilai buku yang lebih besar jika dibandingkan perusahaan yang pengembaliannya rendah (Brigham, 2006).

2. Rasio Keuangan

Rasio keuangan menurut Kasmir (2012) adalah kegiatan membandingkan angka-angka yang ada dalam laporan keuangan dengan cara membagi satu angka dengan angka lainnya.

\section{Current Ratio (CR)}

Current Ratio adalah gambaran seberapa banyak aktiva lancar tersedia untuk menutupi kewajiban jangka pendek yang segera jatuh tempo (Kasmir, 2016).

\section{Return On Equity (ROE)}

Return On Equity adalah gambaran mengenai kemampuan perusahaan memperoleh laba yang tersedia bagi pemegang saham perusahaan (Sartono, 2001).

\section{Debt to Asset Ratio (DAR)}

Debt to Asset Ratio merupakan rasio utang yang digunakan untuk mengukur perbandingan antara total utang dengan total aktiva. Rasio ini merupakan rasio antara total hutang (total debt) dengan total asset (total asset) yang dinyatakan dalam persentase. Rasio ini mengukur berapa persen aset perusahaan yang dibelanjai dengan hutang (Harjito, 2014).

\section{Penelitian Terdahulu}

Chaidir (2015) melakukan penelitian untuk menganalisis pengaruh struktur modal yang diproksikan dengan Debt to Asset Ratio (DAR) dan Debt to Equity Ratio (DER), profitabilitas yang diproksikan dengan Return on Equity (ROE) dan Return on Asset (ROA), dan pertumbuhan perusahaan yang diproksikan dengan Asset Growth terhadap nilai perusahaan yang diproksikan dengan Price Book Value (PBV). Hasil penelitian menunjukan jika secara simultan variabel DAR, DER, ROE, ROA dan Asset Growth berpengaruh positif signikan terhadap PBV, DAR berpengaruh negatif dan signifikan terhadap PBV, DER berpengaruh positif signifikan terhadap PBV, ROE berpengaruh positif signifikan terhadap PBV, ROA tidak berpengaruh positif signifikan terhadap PBV, dan variabel Asset Growth berpengaruh positif signifikan terhadap PBV.

Syarif (2014) melakukan penelitian mengenai analisis pengaruh kinerja keuangan terhadap nilai perusahaan Food and Beverage yang terdaftar di bursa efek indonesia tahun 2008-2012. Hasil penelitian menunjukkan jika current ratio secara parsial tidak berpengaruh yang signifian terhadap nilai perusahaan, Debt to Equity Ratio secara parsial tidak berpengaruh yang signifikan terhadap nilai perusahaan, Gross Profit Margin secara parsial berpengaruh signifikan terhadap niai perusahaan.

\section{Hipotesis}

H1: Current ratio (CR) berpengaruh negatif terhadap price book value (PBV).

$\mathrm{H} 2$ : Return on equity (ROE) berpengaruh positif terhadap price book value (PBV).

H3: Debt to Asset Ratio (DAR) berpengaruh negatif terhadap price book value (PBV). 


\section{METODE PENELITIAN \\ Populasi dan Sampel \\ Populasi dalam penelitian ini adalah} perusahaan-perusahaan yang bergerak di bidang layanan jasa advertising, printing, dan media dan merupakan perusahaan yang termasuk dalam daftar papan utama di Bursa Efek Indonesia. Populasi dalam penelitian ini berjumlah 15 perusahaan yang telah go public dan memiliki kinerja yang berfluktuasi.

Sampel dalam penelitian ini berjumlah 15 perusahaan. Teknik pengambilan sampel yang digunakan adalah Purposive Sampling di mana penelitian ini tidak dilakukan pada seluruh populasi, tapi terfokus pada target dengan mempertimbangkan kriteriakriteria tertentu yang telah dibuat terhadap objek yang sesuai dengan tujuan penelitian, dalam hal ini penelitian dilakukan pada perusahaan perusahaan yang terdaftar di Bursa Efek Indonesia. Kriteria-kriteria tertentu yang telah dibuat oleh peneliti terhadap objek dalam penelitian ini adalah sebagai berikut:

a. Perusahaan advertising, printing dan media yang terdaftar di Bursa Efek Indonesia periode tahun 2014-2017.

b. Perusahaan bidang layanan jasa advertising, printing dan media yangmemiliki data penelitian yang tidak lengkap selama periode penelitian.

c. Perusahaan yang menerbitkan laporan keuangan dengan rupiah.

\section{Definisi Operasional}

1. Variabel Dependen

Variabel dependen yang dimaksud dalam penelitian ini adalah nilai perusahaan. Nilai perusahaan diukur dengan price book value (PBV) yaitu rasio atas harga pasar saham terhadap nilai buku pada perusahaan Jasa yang terdaftar di Bursa Efek Indonesia periode 2014-2017 dengan sub sektor Advertising, Printing dan Media. Rasio ini digunakan untuk menilai ekuitas berdasarkan nilai bukunya.

2. Variabel Independen

a. Current Ratio (CR)

Current Ratio adalah gambaran seberapa banyak aktiva lancar tersedia untuk menutupi kewajiban jangka pendek yang segera jatuh tempo (Kasmir, 2016).

b. Return On Equity (ROE)

Menurut Jogiyanto (2010), Return on Equity (ROE) adalah salah satu rasio profitabilitas yang mengukur kemampuan perusahaan untuk menghasilkan laba dengan berdasarkan modal saham tertentu. Rasio ini merupakan ukuran profitabilitas dari sudut pandang pemegang saham.

c. Debt to Asset Ratio (DAR)

Menurut Syamsuddin (2007) menyatakan rasio ini mengukur berapa besar aktiva yang dibiayai oleh kreditur. Semakin tinggi debt ratio semakin besar jumlah modal pinjaman yang digunakan di dalam menghasilkan keuntungan bagi perusahaan.

\section{Teknik Analisis Data}

1. Analisis Statistik

Menurut Sugiyono statistik deskriptif adalah statistik yang digunakan untuk menganalisa data dengan cara mendeskripsikan atau menggambarkan data yang telah terkumpul sebagaimana adanya tanpa bermaksud membuat kesimpulan yang berlaku untuk umum.

2. Asumsi Klasik

\section{a. Uji Normalitas}

Pengujian normalitas memiliki tujuan untuk menguji apakah dalam model regresi, variabel pengganggu atau residual memiliki distribusi 
normal. Seperti diketahui bahwa uji $\mathrm{T}$ dan uji $\mathrm{F}$ mengasumsikan bahwa nilai residual mengikuti distribusi normal. Kalau asumsi ini dilanggar maka uji statistik menjadi tidak valid untuk jumlah sampel kecil.

Untuk menguji normalitas data, penelitian ini menggunakan analisis grafik. Pengujian normalitas melalui analisis grafik adalah dengan cara menganalisis grafik normal probability plot yang membandingkan distribusi kumulatif dari distribusi normal. Distribusi normal akan membentuk satu garis lurus diagonal, dan plotting data residual akan dibandingkan dengan garis diagonal. Data dapat dikatakan normal jika data atau titik-titik terbesar di sekitar garis diagonal dan penyebarannya mengikuti garis diagonal. Pada prinsipnya normalitas dapat dideteksi dengan melihat penyebaran data (titik) pada sumbu diagonal dari grafik atau dengan melihat histogram dari residualnya. Dasar pengambilan keputusannya adalah:

a. Jika data menyebar di sekitar garis diagonal dan mengikuti arah garis diagonal atau grafik histogramnya menunjukkan pola distribusi normal, maka model regresi memenuhi asumsi normalitas.

b. Jika data menyebar lebih jauh dari diagonal dan atau tidak mengikuti arah garis diagonal atau grafik histogram tidak menunjukkan pola distribusi normal, maka model regresi tidak memenuhi asumsi normalitas (Ghozali, 2006).

\section{b. Uji Multikolinieritas}

Uji multikolinearitas merupakan keadaan dimana ada hubungan linier secara sempurna atau mendekati sempurna antara variabel independen dalam model regresi (Priyatno, 2010). Menurut Priyatno (2010), variabel yang menyebabkan multikolinearitas dapat dilihat dari nilai toleransi yang lebih kecil dari 0,1 atau nilai VIF yang lebih besar dari nilai 10 . Tujuan dilakukan uji multikolinearitas adalah untuk menguji apakah model regresi ditemukan adanya korelasi antar variabel independen. Model regresi yang baik sebaiknya terbebas dari korelasi di antara variabel independen

c. Uji Heteroskedastisitas

Uji heteroskedastisitas ini bertujuan untuk menguji apakah dalam model regresi terjadi ketidaksamaan varians dari residual satu pengamatan ke pengamatan lain. Jika varians dari satu pengamatan ke pengamatan yang lain tetap, maka disebut homoskedositas atau tidak terjadi heteroskedastisitas dan jika varians berbeda maka disebut heteroskedastisitas. Model regresi yang baik adalah yang homoskedastisitas atau tidak terjadi heteroskedasitas (Ghozali, 2006).

Uji heteroskedastisitas bertujuan untuk menguji apakah dalam sebuah model regresi, terjadi ketidaksamaan varians atau residual dari satu pengamatan ke pengamatan yang lain. Menurut Gujarati (2012) untuk menguji ada tidaknya heteroskedastisitas digunakan ujirank Spearman, yaitu dengan mengkorelasikan variabel independen terhadap nilai absolut dari residual (error). Untuk mendeteksi gejala uji heteroskedastisitas, maka dibuat persamaan regresi dengan asumsi tidak ada heteroskedastisitas kemudian menentukan nilai absolut residual, selanjutnya meeregresikan nilai absolute 
residual diperoleh sebagai variabel dependen serta dilakukan regresi dari variabel independen. Jika nilai koefisien korelasi antara variabel independen dengan nilai absolut dari residual signifikan, maka kesimpulannya terdapat heteroskedastisitas (varian dari residual tidak homogen).

\section{d. Uji Autokorelasi}

Uji autokorelasi bertujuan untuk mengetahui apakah dalam suatu model regresi linier terdapat korelasi antara pengganggu pada periode $\mathrm{t}$ dengan kesalahan pada periode t-1 (sebelumnya). Model regresi yang baik adalah regresi yang bebas dari autokeralasi (Ghozali, 2006).

\section{Analisis Regresi Berganda}

Menurut Ghozali (2011) persamaan regresi linier berganda dapat dinyatakan sebagai berikut:

$\mathrm{PBV}=\mathbf{a}+\mathbf{b} 1 \mathrm{CR}+\mathbf{b} 2 \mathrm{ROE}+\mathbf{b} 3 \mathrm{DAR}$

Keterangan:

$\mathrm{Y}=$ variabel $\mathrm{PBV}$

$\alpha=$ konstanta

b1,b2,b3 =Koefisian regresi dari masing-masing variabel bebas

$\mathrm{CR}=$ Current Ratio

ROE $=$ Return On Equity

DAR $=$ Debt to Asset Ratio

\section{Uji Parsial (Uji T)}

Koefisien regresi digunakan untuk mengetahui pengaruh variabel independen secara parsial terhadap variabel dependen. Pengujian terhadap hasil regresi dilakukan menggunakan uji $\mathrm{t}$ pada derajat keyakinan sebesar $95 \%$ atau $\propto=5 \%$.

Dengan menggunakan besarnya nilai signifikan :

1) Pengujian Hipotesis (H1)

Jika nilai signifikansi uji $\mathrm{t}$ (pada kolom Sig.) < 0,05 maka H0 ditolak dan $\mathrm{Ha}$ diterima, artinya CR berpengaruh terhadap PBV dan sebaliknya jika nilai signifikan > 0,05 maka tidak berpengaruh.

2) Pengujian Hipotesis (H2) Jika nilai signifikansi uji $\mathrm{t}$ (pada kolom Sig.) < 0,05 maka H0 ditolak dan Ha diterima, ROE berpengaruh terhadap PBV dan sebaliknya jika nilai signifikan > 0,05 maka tidak berpengaruh.

3) Pengujian Hipotesis (H3)

Jika nilai signifikansi uji $\mathrm{t}$ (pada kolom Sig.) < 0,05 maka H0 ditolak dan $\mathrm{Ha}$ diterima, artinya DAR berpengaruh signifikan terhadap PBV dan sebaliknya jika nilai signifikan >0,05 maka tidak berpengaruh.

\section{Uji Koefisien Determinasi}

Uji R2 digunakan untuk menguji seberapa besar kemampuan model dalam menerangkan variasi variabel dependen. Nilai koefisien determinasi adalah antar nol sampai satu $\left(0<\mathrm{R}^{2}<1\right)$. Nilai $\mathrm{R}^{2}$ yang kecil berarti kemampuan variabel-variabel independen dalam menjelaskan variasi variabel dependen amat terbatas. Nilai yang mendekati satu berarti variabelvariabel independen memberikan hampir semua informasi yang dibutuhkan untuk memprediksi variasi variabel dependen (Ghozali, 2006). 


\section{HASIL PENELITIAN DAN PEMBAHASAN}

\section{Hasil Penelitian}

1. Hasil Analisis Statistik Deskriptif Hasil Statistik Desktiptif:

\begin{tabular}{|c|c|c|c|c|}
\hline & Minimum & Maximum & Mean & $\begin{array}{c}\text { Std. } \\
\text { Deviation }\end{array}$ \\
\hline PBV & 0,09 & 5,17 & 1,9675 & 1,27710 \\
\hline ROE & $-34,12$ & 44,57 & 6,9547 & 17,04577 \\
\hline CR & 19,33 & 779,79 & 225,7382 & 163,14033 \\
\hline DAR & 0,04 & 0,79 & 0,3940 & 0,19713 \\
\hline
\end{tabular}

Berikut penjelasan mengenai hasil analisis statistik deskriptif:

a. Price Book Value (PBV)

Hasil uji analisis statistik deskriptif menunjukkan Price Book Value (PBV) (Y) pada perusahaan sub sektor Advertising, Printing, dan Media yang terdaftar di BEI periode 2014-2017 rata-rata (mean) sebesar 1,9675, dengan standar deviasi sebesar 1,27710. Price Book Value (PBV) tertinggi yaitu 5,17dan yang terendah yaitu 0,09 .

b. Current Ratio (CR)

Hasil uji analisis statistik deskriptif menunjukkan Current Ratio (CR) (X2) pada perusahaan sub sektor Advertising, Printing, dan Media yang terdaftar di BEI periode 2014-2017 rata-rata (mean) sebesar 225,7382 dengan standar deviasi sebesar 163,14033. Return on Equity (ROE) tertinggi yaitu 779,79 dan yang terendah yaitu 19,33 .

c. Return On Equity (ROE)

Hasil uji analisis statistik deskriptif menunjukkan Return on Equity (ROE) (X2) pada perusahaan sub sektor Advertising, Printing, dan Media yang terdaftar di BEI periode 2014-2017 rata-rata (mean) sebesar 6,9547 dengan standar deviasi sebesar 17,04577. Return on Equity (ROE) tertinggi yaitu 44,57 dan yang terendah yaitu $-34,12$.

d. Debt to Asset Ratio (DAR)

Hasil uji analisis statistik deskriptif menunjukkan Debt to Asset Ratio (DAR) (X3) pada perusahaan sub sektor Advertising, Printing, dan Media yang terdaftar di BEI periode 2014-2017 rata-rata (mean) sebesar 0,3940 dengan standar deviasi sebesar 0,19713. Debt to Asset Ratio (DAR) tertinggi yaitu 0,79 dan yang terendah yaitu 0,04 .

2. Hasil Uji Asumsi Klasik

a. Uji Normalias

Tahap 1

\begin{tabular}{|c|c|} 
Hasil Uji Normalitas: \\
\hline Asymp. Sig (2-tailed) & 0,017 \\
\hline
\end{tabular}
hasil Uji Kolmogorov-Smirnov dapat disimpulkan bahwa persamaan diatas berdistribusi tidak normal, hal ini ditunjukkan pada nilai Asymp. Sig (2-tailed) sebesar 0,017, yang mana lebih kecil dari $\alpha 5 \%(0,017<$ $0,05)$.

Tahap 2

Tabel Hasil Uji Normalitas dengan Uji Kolmogorov-Smirnov:

\begin{tabular}{|l|c|}
\hline Asymp. Sig (2-tailed) & 0,899 \\
\hline
\end{tabular}

Berdasarkan hasil uji normalitas menggunakan

Kolmogorov-Smirnov setelah dilakukan perbaikan pada tabel di atas. Untuk mengatasi masalah normalitas yaitu dengan menggunakan scatter plot pada excel dengan menghilangkan data yang outlayer, kemudian data yang dihilangkan tersebut diganti dengan nilai rata-rata dari keseluruhan 
datanya. Data diuji dengan menggunakan uji KolmogorovSmirnov. Berdasarkan hasil uji normalitas menunjukkan bahwa residual persamaan regresi pada uji normalitas dengan menggunakan uji KolmogorovSmirnov dapat disimpulkan bahwa persamaan diatas berdistribusi normal, hal ini ditunjukkan pada nilai Asymp. Sig (2-tailed) sebesar 0,899 , yang mana lebih besar dari $\alpha$ $5 \%(0,899>0,05)$.

b. Uji Multikolinieritas Hasil uji Wultikoliniertas:

\begin{tabular}{|c|c|c|}
\hline Model & Tolerance & VIF \\
\hline ROE & 0,711 & 1,296 \\
\hline CR & 0,761 & 1,314 \\
\hline DAR & 0,743 & 1,445 \\
\hline
\end{tabular}

Berdasarkan hasil uji di atas, diketahui nilai VIF variable ROE 1,296, variabel $\mathrm{CR}$ 1,314, dan variabel DAR 1,345. Karena nilai VIF untuk semua variabel tersebut $<$ 10, maka dapat disimpulkan persamaan diatas tidak terdapat gejala Multikolinieritas. Dapat juga dilihat dari nilai Tolerance variabel CR 0,771, variabel CR 0,761, dan variabel DAR 0,743. Karena nilai Tolerance untuk semua variabel tersebut > 0,01, maka dapat disimpulkan persamaan diatas tidak terdapat gejala Multikolinieritas. c. Uji Heteroskedastisitas

Hasil uji Heterokedastisitas

\begin{tabular}{|c|c|}
\hline Spearman's rho & $\begin{array}{c}\text { Sig (2-tailed) } \\
\text { Unstandardized Residual }\end{array}$ \\
\hline ROE & 0,712 \\
\hline CR & 0,492 \\
\hline DAR & 0,876 \\
\hline
\end{tabular}

Berdasarkan hasil uji menggunakan Rank Spearman diatas diketahui nilai Sig (2-tailed) ROE 0,712, CR 0,492, dan DAR 0,876, karena semua nilai variabel Sig (2tailed) $>\alpha 5 \%$, maka dapat disimpulkan persamaan di atas tidak terdapat gejala Heteroskedastisitas.

d. Uji Autokorelasi

Tahap 1

Hasil Uji Durbin-Watson:

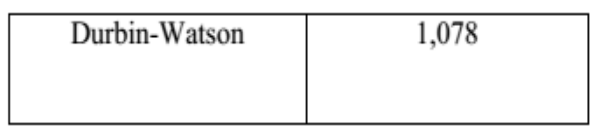

Berdasarkan tabel di atas, hasil uji Durbin-Watson adalah 1,078, dengan $\mathrm{n}=56$ dan $\mathrm{k}=4$, diperoleh nilai table $\mathrm{D}-\mathrm{W}$, $\mathrm{DL}=1,4581$ dan $\mathrm{DU}=1,6830$. Dapat disimpulkan sebagai berikut:

$0<1,078<1,4581$

$0<\mathrm{DW}<\mathrm{DL}=$ maka terjadi autokorelasi positif

Untuk mengatasi masalah autokorelasi di atas, maka peneiti melakukan transformasi data dengan metode Cochrane-Orcutt. Dengan cara transfrmasi Lag, Lag artinya mengembalikan variabel baru yang merupakan hasil pengurangan nilai dari sampel ke-i-1. Sampel ke-i artinya sampel yang sebelumnya dan sampel ke-i-1 adalah sampel sebelumnya dari sampel yang bersangkutan.dan didapat nilai koefisien rho sebesar 0,466. 
Di bawah ini adalah hasil transformasi Lag dengan Uji Cochrane Orcutt:

\section{Tahap 2}

Hasil Uji Durbin-Watson:

\begin{tabular}{|c|c|}
\hline Durbin-Watson & 2,009 \\
& \\
\hline
\end{tabular}

Berdasarkan tabel di atas, hasil uji Durbin-Watson adalah 2,009, dengan $\mathrm{n}=56$ dan $\mathrm{k}=3$, diperoleh nilai tabel $\mathrm{D}-\mathrm{W}$, $\mathrm{DL}=1,4581$ dan $\mathrm{DU}=1,6830$. Dapat disimpulkan sebagai berikut: $1,6830<2,009<2,317(4-1,6830)$ DU $<$ DW $<4-$ DU $=$ tidak terjadi autokorelasi

3. Hasil Analisis Regresi Berganda Hasil Uji Regresi Linier Berganda

\begin{tabular}{|c|c|}
\hline Model & B \\
\hline (Constant) & 2,213 \\
\hline ROE & 0,030 \\
\hline CR & 0,000 \\
\hline DAR & $-1,449$ \\
\hline
\end{tabular}

Berdasarkan tabel uji regresi linier berganda di atas, didapatkan hasil:

$\mathrm{PBV}=\mathbf{a}+\mathbf{b} 1 \mathrm{ROE}+\mathbf{b} 2 \mathrm{CR}+\mathbf{b} 3 \mathrm{DAR}$ $\mathrm{PBV}=2,213+0,030 \mathrm{ROE}+0,000 \mathrm{CR}$ $-1,449$ DAR

Dari persamaan model regresi linear tersebut dapat diinterprestasikan sebagai berikut:

a. Konstanta (a)

Nilai konstanta (a) sebesar 2,213 menunjukkan bahwa apabila nilai variabel ROE,CR, dan DAR naik satu satuan, maka nilai variabel PBV naik sebesar 2,213. b. Koefisien b1 untuk variabel ROE

Besarnya nilai koefisien regresi (b1) sebesar 0,030, nilai b1 yang positif menunjukkan adanya hubungan yang searah antara variabel PBV dengan variabel ROE yang artinya jika nilai variabel ROE turun sebesar 1 maka nilai PBV akan naik sebesar 2,213.

c. Koefisien b2 untuk variabel CR

Besarnya nilai koefisien regresi (b2) sebesar 0,000 , nilai b2 yang positif menunjukkan adanya hubungan yang searah antara variabel PBV dengan variabel $\mathrm{CR}$ yang artinya jika nilai variabel $\mathrm{CR}$ turun sebesar 1 maka nilai PBV akan naik sebesar 2,213.

d. Koefisien b3 untuk variabel DAR

Besarnya nilai koefisien regresi (b3) sebesar - 1,449, nilai b3 yang negatif menunjukkan adanya hubungan yang berlawanan arah antara variabel PBV dengan variabel CR yang artinya jika nilai variabel DAR turun sebesar 1 maka nilai PBV akan naik sebesar 2,213.

4. Hasil Uji Parsial (Uji T)

\begin{tabular}{|c|c|c|}
\hline \multicolumn{1}{|c|}{ Hasil Uji t: } \\
\hline Model & Sig. & Kesimpulan \\
\hline (Constant) & & \\
\hline ROE & 0,005 & Terima H1 \\
\hline CR & 0,646 & Tolak H2 \\
\hline DAR & 0,100 & Tolak H3 \\
\hline
\end{tabular}

Berdasarkan hasil uji $\mathrm{t}$ di atas, didapatkan hasil :

a. Nilai signifikansi (Sig.) ROE sebesar 0,005 < 0,05 ( $\alpha$ 5\%). Maka dapat disimpulkan bahwa $\mathrm{H} 1$ diterima. Artinya ROE berpengaruh dan signifikan terhadap PBV.

b. Nilai signifikansi (Sig.) CR sebesar $0,646>0,05(\alpha \quad 5 \%)$. Maka dapat 
disimpulkan bahwa $\mathrm{H} 2$ ditolak. Artinya CR tidak berpengaruh dan tidak signifikan terhadap PBV.

c. Nilai signifikansi (Sig.) DAR sebesar 0,100 >0,05 ( $\alpha$ 5\%). Maka dapat disimpulkan bahwa $\mathrm{H} 3$ ditolak. Artinya DAR tidak berpengaruh dan tidak signifikan terhadap PBV.

5. Hasil Uji Koefisien Determinasi

Hasil Uji R Square:

\begin{tabular}{|c|c|}
\hline R Square & 0,307 \\
& \\
\hline
\end{tabular}

Berdasarkan tabel hasil uji $\mathrm{R}$ Square di atas, dapat dilihat nilai koefisien determinasi ( $\mathrm{R}$ Square ) sebesar 0,307 atau 30,7\% dari variabel ROE, CR, dan DAR, sedangkan sisanya $69,3 \%$ dijelaskan atau dipengaruhi oleh variabel-variabel (faktor atau rasio-rasio keuangan) lain yang tidak termasuk dalam model.

\section{Pembahasan}

1. Pengaruh Current Ratio (CR) terhadap Price Book Value (PBV)

Berdasarkan hasil analisis uji $\mathrm{t}$ menunjukkan bahwa variabel $\mathrm{CR}$ memiliki nilai signifikansi (Sig.) CR sebesar 0,646>0,05 ( $\alpha$ 5\%). Maka dapat disimpulkan bahwa Ha ditolak. Artinya CR berpengaruh positif dan tidak signifikan terhadap PBV. Dengan demikian hipotesis yang menyatakan bahwa $\mathrm{CR}$ berpengaruh positif terhadap PBV ditolak. Pengaruh yang tidak signifikan menunjukkan bahawa selama ini perusahaan sub sektor Advertising, Printing dan Media belum mampu memenuhi kewajiban jangka pendeknya (termasuk didalamnya kewajiban membayar dividen kas yang terutang). Hal ini sesuai dengan penelitian Syarif (2014) dimana hasil penelitiannya menyatakan bahwa Current Ratio (CR) tidak berpengaruh signifikan terhadap Price Book Value (PBV).

2. Pengaruh antara Return on Equity (ROE) terhadap Price Book Value (PBV).

Berdasarkan hasil analisis uji $\mathrm{t}$ menunjukkan bahwa variabel ROE memiliki nilai signifikansi (Sig.) ROE sebesar $0,005<0,05(\alpha$ 5\%). Maka dapat disimpulkan bahwa Ha diterima. Artinya ROE berpengaruh positif dan signifikan terhadap PBV. Dengan demikian hipotesis yang menyatakan bahwa ROE berpengaruh positif terhadap PBV ditolak. Hasil tersebut menunjukkan bahwa perusahaan sub sektor Advertising, Printing dan Media sudah mampu menunjukkan tingkat kembalian yang dihasilkan oleh manajemen dari modal yang disediakan oleh pemilik perusahaan. Hal ini sesuai dengan penelitian yang di lakukan Ayu (2013) dalam penelitiannya menunjukkan bahwa Return On Equity (ROE) secara parsial berpengaruh positif signifikan terhadap nilai perusahaan.

3. Pengaruh Debt to Asset Ratio (DAR) terhadap Price Book Value (PBV).

Berdasarkan hasil analisis uji $t$ menunjukkan bahwa variabel DAR memiliki nilai signifikansi (Sig.) DAR sebesar $0,100>0,05(\alpha$ 5\%). Maka dapat disimpulkan bahwa Ha ditolak. Artinya DAR berpengaruh positif dan tidak signifikan terhadap PBV. Dengan demikian hipotesis yang menyatakan bahwa DAR berpengaruh positif terhadap PBV ditolak. Pengaruh yang tidak signifikan menunjukkan bahwa selama ini perusahaan sub sektor Advertising, Printing dan Media belum mampu memiliki pendanaan dengan utang semakin banyak, maka semakin sulit bagi perusahaan untuk 
memperoleh tambahan pinjaman karena dikhawatirkan perusahaan tidak mampu menutupi utang-utangnya dengan aktiva yang dimilikinya. Hal ini sesuai dengan penelitian oleh penelitian Chaidir (2015) dimana hasil penelitiannya menyatakan bahwa Debt to Asset Ratio (DAR) tidak berpengaruh signifikan terhadap Price Book Value (PBV).

4. Hasil Koefisien Determinan (R2)

Berdasarkan hasil uji $\mathrm{R}$ Square, dapat dilihat nilai koefisien determinasi (R-Square) sebesar 0,307 atau 30,7\% dari variabel Price Book Value (PBV) dapat dijelaskan oleh Debt To Asset Ratio (DAR), Current Ratio (CR), Return on Equity (ROE), sedangkan sisanya $69,3 \%$ dijelaskan atau dipengaruhi oleh variabel-variabel (faktor atau rasio-rasio keuangan) lain yang tidak termasuk dalam model.

\section{KESIMPULAN DAN SARAN}

\section{Kesimpulan}

Berdasar hasil analisis yang telah dibahas pada bab sebelumnya, maka dapat diambil kesimpulan sebagai berikut:

1. Return On Equity (ROE) secara parsial berpengaruh positif signifikan terhadap Price Book Value (PBV) pada perusahaan Advertising, Printing dan Media yang terdaftar di Bursa Efek Indonesia periode 2014-2017.

2. Current Ratio (CR) secara parsial berpengaruh positif dan tidak signifikan terhadap Price Book Value (PBV) pada perusahaan Advertising, Printing dan Media yang terdaftar di Bursa Efek Indonesia periode 2014-2017.

3. Debt to Asset Ratio (DAR) secara parsial berpengaruh positif dan tidak signifikan terhadap Price Book Value (PBV) pada perusahaan Advertising, Printing dan Media yang terdaftar di
Bursa Efek Indonesia periode 20142017.

\section{Saran}

1. Penelitian ini menggunakan periode pengamatan yang relatif masih pendek yaitu empat tahun, peneliti selanjutnya disarankan untuk menambah periode pengamatan sehingga akan mendapatkan hasil yang lebih baik.

2. Bagi akademis/ilmu pengetahuan disarankan agar hasil penelitian ini dapat dijadikan masukan informasi yang bermanfaat dalam pengetahuan penelitian yang lebih baik lagi berhubungan dengan manajemen keuangan

3. Penelitian ini menunjukkan bahwa Price Book Value dipengaruhi oleh Current Ratio, Return On Equity, dan Debt To Asset Ratio, sehingga peneliti menyarankan bagi investor yang ingin menanamkan modalnya sebaiknya memperhatikan variabel tersebut sebagai pertimbangan sebelum mengambil keputusan untuk menanamkan modal.

4. Penelitian selanjutnya dapat menambah variabel penelitian sehingga variabel penelitian tidak hanya bersumber dari laporan keuangan saja, peneliti selanjutnya bisa menambah variabel penelitian lain misalnya faktor-faktor makro ekonomi seperti inflasi, tingkat bunga, nilai tukar rupiah, pertumbuhan ekonomi, dan variabel lainnya.

5. Penelitian selanjutnya dapat menggunakan proksi yang berbeda untuk variabel nilai perusahaan misalnya Price to Earning Ratio (PER). 


\section{DAFTAR PUSTAKA}

Adyatma, Erdi dan Rahmawati Meita Oktaviani. (2015). Pengaruh Pendapatan Asli Daerah dan Dana Alokasi Umum Terhadap Belanja Modal Dengan Pertumbuhan Ekonomi Sebagai Pemoderasi. ISSN 1979-4878, Volume 4 Nomor 2 Nopember 2015.

Brahmana, Rayenda K. (2007). Identifying Financial Distress Condition in Indonesia Manufacture Industry. Birmingham Business School. University of Birmingham United Kingdom. Halaman 1-19.

Brigham, Eugene F dan Houston. (2006). Fundamental of Financial Management: Dasar-Dasar Manajemen Keuangan. Edisi 10. Jakarta: Salemba Empat.

Chaidir. (2015). Pengaruh Struktur Modal, Profitabilitas, dan Pertumbuhan Perusahaan terhadap Nilai Perusahaan pada Perusahaan Sub Sektor Transportasi yang Tercatat di Bursa Efek Indonesia Periode 2012-2014. Jurnal Ilmiah Manajemen Fakultas Ekonomi.

Dewi, Ayu., dan Ary Wirajaya. (2013). Pengaruh Struktur Modal dan Ukuran Perusahaan Pada Nilai Perusahaan. E-Jurnal Akuntansi. Universitas Udayana.

Ghozali, Imam. (2006). Aplikasi Analisis Multivariate Dengan Program SPSS. Cetakan Keempat. Semarang: Badan Penerbit Universitas Diponegoro.

Gujarati, D.N. (2012). Dasar-Dasar Ekonometrika Teremahan Mangunsong. R.C. Jilid 2 Edisi 5. Jakarta: Salemba Empat.
Harjito, A dan Martono. (2014). Manajemen Keuangan. Edisi ke-2 Cetakan Keempat. Yogyakarta: Ekonisia.

Jogiyanto. (2010). Metodologi Penelitian Bisnis. Yogyakarta: BPFE.

Kasmir. (2012). Analisis Laporan Keuangan. Jakarta: Raja Grafindo Persada.

Kasmir. (2016). Analisis Laporan Keuangan. Jakarta: Raja Grafindo Persada.

Priyatno, Duwi. (2010). Paham Analisa Statistik Data Dengan SPSS. Yogyakarta: Mediakom.

Sartono, Agus. (2001). Manajemen Keuangan. Yogyakarta : BPFE.

Sugiyono. (2012). Memahami Penelitian Kualitatif. Bandung: Alfabeta.

Syamsuddin, Lukman. (2007). Manajemen Keuangan Perusahaan : Konsep Aplikasi dalam Perencanaan, Pengawasan, dan Pengambilan Keputusan. Jakarta: Raja Grafindo Persada.

Syarif. (2014). Analisis Pengaruh Kinerja Keuangan Terhadap Nilai Perusahaan (Studi Kasus Pada Perusahaan Food And Baverage Yang Terdaftar Di Bursa Efek Indonesia Tahun 2008-2012). Skripsi. Universitas Muhammadiyah Surakarta 